\title{
General Bibliography
}

The standard edition of Descartes' works is Oeuvres de Descartes, publies par Ch[arles] Adam et P[aul] Tannery (Vrin, 1957-1974). Vrin prints both the Latin and the French texts of the Meditations, Vols. VII and IX. References to this edition are abbreviated as AT. The edition and translation of Elizabeth S. Haldane and G. R. T. Ross, The Philosophical Works of Descartes (Cambridge: Cambridge University Press; reprinted 1969), is cited as HR. References to Descartes: Philosophical Letters, translated and edited by Anthony Kenny (Oxford: Clarendon Press, 1970) are standardly abbreviated as K. The Discourse on Method; Optics, Geometry and Meteorology was translated with an introduction by Paul J. Olscamp (Indianapolis: Bobbs-Merrill, 1965). The comprehensive bibliography of works on Descartes is Gregor Sebba's Bibliographia Cartesiana (The Hague: Nijhoff, 1964). For a sound and selective bibliography on Descartes after 1964, consult the bibliography in Margaret Dauler Wilson's Descartes (London: Routledge \& Kegan Paul, 1978), pp. 245-250. See also the excellent bibliography gathered by Willis Doney, published in Michael Hooker's Descartes: Critical and Interpretive Essays (Baltimore: Johns Hopkins University Press, 1978). Another useful source is Stephen Gaukroger's collection, Descartes: Philosophy, Mathematics and Physics (Sussex, N.J.: Barnes and Noble, 1980). 
